\title{
A Novel Method for Measuring the Performance of Software Project Managers
}

\author{
Jasem M. Alostad \\ The Public Authority for Applied Education and Training (PAAET), College of Basic Education \\ P.O. Box.23167, Safat 13092, Kuwait
}

\begin{abstract}
This paper is focused on providing a novel method for measuring the performance of software project managers. It clarifies the fundamental concepts of software project management, knowledge areas, life cycle phases of software project, and performance metrics. It presents some examples of processes and common performance metrics related to knowledge areas of software project management. The researcher extracts an enhanced list of performance metrics using a questionnaire that is passed to 60 experts and specialists in the field of software projects. Their responses are collected and filtered for reaching to effective performance metrics and the importance degree of each one. The researcher adapts Goal Question Metrics method to include an additional step that dedicated to calculate a performance indicator for each knowledge area of software project management. Finally, the new method has been applied on 3 real software projects to measure the performance of their managers. Measuring the performance of software project managers can be helpful in controlling and improving the performance.
\end{abstract}

Keywords-software project manager; performance; measurement; metrics; indicators; Goal Question Metrics method; schedule management

\section{INTRODUCTION AND PROBLEM DEFINITION}

The knowledge and skills required for effective project managers in an Information Technology (IT) environment fall into four domains [1]: project management competencies, industry and/or business competencies, IT management practices, and general management competencies. In this paper, the researcher focuses on the project management competencies which include the IT practices. The researcher doesn't focus on the industry and/or business competencies because they differ from one project to another. Also, the researcher doesn't focus on the general management competencies because they are basic knowledge and skills required for any project manager. Each project management competency and its IT ramifications will be explained as a specific knowledge area of Software Project Management (SPM).

Software development is a mentally complicated process. Therefore, SPM is the art and science of planning and leading software projects [2]. SPM is the on-going activities for planning, organizing, directing, and controlling progress to develop an acceptable system, i.e. conform to the quality standards within the allocated time and budget [3]. Software Project (SP) manager is a person who undertakes the responsibility of executing the SP. Software project manager is thoroughly aware of all the phases of software development process that the software would go through. A project manager closely monitors the development process, prepares and executes various plans, arranges necessary and adequate resources, maintains communication among all team members in order to address issues of cost, budget, resources, time, quality, and customer satisfaction [4].

The mismanaged projects may lead to: unfulfilled or unidentified requirements, uncontrolled change of the project scope, uncontrolled change of technology, uncontrolled risk of the project, uncontrolled subcontracting and integration, cost overruns, and/or late delivery [5]. However the number of successful SPs is few compared to the total number of software projects [6]. Figure 1 illustrates a part of a research performed by Standish Group that includes the percentage of successful, failed, and challenged software projects from year 2004 to year 2012 resulted from CHAOS manifesto [7].

\begin{tabular}{|l|c|c|c|c|c|}
\hline & $\mathbf{2 0 0 4}$ & $\mathbf{2 0 0 6}$ & $\mathbf{2 0 0 8}$ & $\mathbf{2 0 1 0}$ & $\mathbf{2 0 1 2}$ \\
\hline Successful & $29 \%$ & $35 \%$ & $32 \%$ & $37 \%$ & $39 \%$ \\
\hline Failed & $18 \%$ & $19 \%$ & $24 \%$ & $21 \%$ & $18 \%$ \\
\hline Challenged & $53 \%$ & $46 \%$ & $44 \%$ & $42 \%$ & $43 \%$ \\
\hline
\end{tabular}

Fig. 1. Project resolution results from CHAOS research [7]

This research finds that around $60 \%$ of software projects were challenged or failed through the years 2004 to 2012. Because of the high percentage of failure, some research efforts are initiated to improve the performance of SP managers.

This paper contributes in these efforts by providing a quantitative method for measuring the performance of SP managers at any point of time in the project life or at the end of a specific phase. The proposed method depends on an enhanced list of performance metrics and simple mathematical and statistical techniques. In addition, the proposed method depends on an adapted version of GQM method that can provide an organized method of thinking in this field. GQMI delivers an enhanced list of metrics and indicators that can be used for evaluating the performance of SP manager in order to improve and develop it. Performance indicators give a significant image about the pitfalls in the performance and then assist the management to direct the SP managers to improve their performance.

The rest of the paper is organized as follows: Section II provides a background overview about the main concepts related to the research topic. Section III presents some 
significant related work focusing on measuring the performance of SP managers. Section IV presents how to reach to the enhanced list of performance metrics and GQMI. Section $\mathrm{V}$ presents how to apply GQMI on real projects. Section VI concludes the paper with final remarks. The last section includes the ideas that are expected to be focused on the future.

\section{BACKGROUND OVERVIEW}

This section consists of three parts. The first part presents the main concepts related to SPM. The second part provides an overview of performance metrics of SPM. The final part gives an explanation of GQM.

\section{A. SPM Areas and Project Phases}

SPM is the process of planning, organizing, staffing, monitoring, controlling and leading a software project. SPM activities can be organized in nine knowledge areas [1]: integration management, scope management, schedule/time management, costs management, quality management, human resources management, communications management, risk management, and procurement management. A new knowledge area was added in PMBOK 5th edition [8, 9], which is "stakeholder management".

- Project integration management includes the processes required to ensure that the various elements of the project are properly coordinated [1]. It involves bringing people and things together to perform effectively. It includes the integration of functionality, data, and/or interfaces.

- Project scope management involves activities to define and control what is included in the project and what is out of its scope.

- Project schedule/time management is the administration and control of the finite resource of time to prevent or correct any slippages [8].

- Project cost management is the planning and control required to ensure that a project is completed within the approved budget.

- Project quality management involves those activities that ensure the project delivers the systems that satisfy the project objectives. The project manager must ensure that the quality activities are implemented and applied throughout the project life cycle.

- Project human resources management involves those processes required to make the most effective use of the people involved in a project [1]. The project manager must identify and implement strategies to re-skill the existing IT workforce and acquire external expertise through vendors and consultants when needed [10]. Also, the project manager should establish procedures for involving the system users [11].

- Project communications management involves the timely and appropriate generation, collection, dissemination, storage, and ultimate disposition of project information. Effective communication is one of the critical success factors for IS projects [12].
- Project risk management includes the processes concerned with identifying, analyzing and responding to the project risks, maximizing the results of positive events and minimizing the consequences of adverse events [1].

- Project procurement management includes managing subcontractors because if one of the subcontractors late, this may lead to project slippage. So, the project manager must make everything is clear to subcontractors [11]. Also, the project manager must know the legal and financial issues of subcontracting.

- Project stakeholder management includes the processes required to identify the people, groups, or organizations that could impact or be impacted by the project, to analyze stakeholder expectations and their impact on the project, and to develop appropriate management strategies for effectively engaging stakeholders in project decisions and execution [8].

Each knowledge area includes a set of processes related to a specific field in SPM practices. Table I illustrates the processes required to achieve project schedule/time management, project cost management, project scope management, and project stakeholder management.

TABLE I. EXAMPLE OF THE PROCESSES REQUIRED FOR ACHIEVING SPM KNOWLEDGE AREAS [8]

\begin{tabular}{|c|c|}
\hline Knowledge & Processes \\
\hline $\begin{array}{l}\text { Project } \\
\text { Schedule/Time } \\
\text { Management }\end{array}$ & $\begin{array}{ll}\text { 1. } & \text { Plan Schedule Management } \\
\text { 2. } & \text { Define Activities } \\
\text { 3. } & \text { Sequence Activities } \\
\text { 4. } & \text { Estimate Activity Resources } \\
\text { 5. } & \text { Estimate Activity Durations } \\
\text { 6. } & \text { Develop Schedule } \\
\text { 7. } & \text { Control Schedule }\end{array}$ \\
\hline $\begin{array}{l}\text { Project Cost } \\
\text { Management }\end{array}$ & $\begin{array}{ll}\text { 1. } & \text { Plan Cost Management } \\
\text { 2. } & \text { Estimate Costs } \\
\text { 3. } & \text { Determine Budget } \\
\text { 4. } & \text { Control Costs }\end{array}$ \\
\hline $\begin{array}{l}\text { Project Scope } \\
\text { Management }\end{array}$ & $\begin{array}{ll}\text { 1. } & \text { Plan Scope Management } \\
\text { 2. } & \text { Collect Requirements } \\
\text { 3. } & \text { Define Scope } \\
\text { 4. } & \text { Create WBS } \\
\text { 5. } & \text { Validate Scope } \\
\text { 6. } & \text { Control Scope }\end{array}$ \\
\hline $\begin{array}{l}\text { Project } \\
\text { Stakeholder } \\
\text { Management }\end{array}$ & $\begin{array}{ll}\text { 1. } & \text { Identify Stakeholders } \\
\text { 2. } & \text { Plan Stakeholder Management } \\
\text { 3. } & \text { Management Stakeholder Engagement } \\
\text { 4. } & \text { Control Stakeholder Engagement }\end{array}$ \\
\hline
\end{tabular}

For achieving the purpose of this paper, the researcher will focus on schedule/time management as an example of knowledge areas to explain the novel measuring method. According to PMBOK 5th edition [8] and [9, 13], the inputs, possible tools and techniques, and outputs for each process required for project schedule/time management is illustrated in table II. 
TABLE II. THE INPUTS, TOOLS AND TECHNIQUES, AND OUTPUTS FOR PROJECT SCHEDULE/Time MANAGEMENT [8, 9, 13]

\begin{tabular}{|c|c|c|c|}
\hline Process & Inputs & $\begin{array}{l}\text { Possible tools } \\
\text { and techniques }\end{array}$ & Outputs \\
\hline $\begin{array}{l}\text { Plan } \\
\text { Schedule } \\
\text { Management }\end{array}$ & $\begin{array}{l}\text { - Project management } \\
\text { plan } \\
\text { - Project charter } \\
\text { - Enterprise } \\
\text { Environmental Factors } \\
\text { (EEF) } \\
\text { - Organizational Process } \\
\text { Assets (OPA) }\end{array}$ & $\begin{array}{l}\text { - Expert judgment } \\
\text { - Meetings } \\
\text { - Analytical } \\
\text { techniques }\end{array}$ & $\begin{array}{l}\text { - Schedule } \\
\text { management plan }\end{array}$ \\
\hline $\begin{array}{l}\text { Define } \\
\text { Activities }\end{array}$ & $\begin{array}{l}\text { - Schedule Management } \\
\text { Plan } \\
\text { - Scope baseline } \\
\text { - EEF } \\
\text { - OPA }\end{array}$ & $\begin{array}{l}\text { - Decomposition } \\
\text { - Rolling wave } \\
\text { planning } \\
\text { - Expert judgment }\end{array}$ & $\begin{array}{l}\text { - Activity List } \\
\text { - Activity Attributes } \\
\text { - Milestone list }\end{array}$ \\
\hline $\begin{array}{l}\text { Sequence } \\
\text { Activities }\end{array}$ & $\begin{array}{l}\text { - Schedule management } \\
\text { plan } \\
\text { - Activity List } \\
\text { - Activity Attributes } \\
\text { - Milestone list } \\
\text { - Project scope } \\
\text { management } \\
\text { - EEF } \\
\text { - OPA } \\
\end{array}$ & $\begin{array}{l}\text { - Precedence } \\
\text { Diagraming } \\
\text { Method (PDM) } \\
\text { - Dependencies } \\
\text { - Leads and lags }\end{array}$ & $\begin{array}{l}\text { - Project Schedule } \\
\text { Network Diagrams } \\
\text { - Project document } \\
\text { updates }\end{array}$ \\
\hline $\begin{array}{l}\text { Estimate } \\
\text { Activity } \\
\text { Resources }\end{array}$ & $\begin{array}{l}\text { - Schedule management } \\
\text { plan } \\
\text { - Activity list } \\
\text { - Activity attributes } \\
\text { - Resource calendar } \\
\text { - Risk register } \\
\text { - EEF } \\
\text { - OPA }\end{array}$ & $\begin{array}{l}\text { - Expert judgment } \\
\text { - Alternative } \\
\text { analysis } \\
\text { - Published } \\
\text { estimating data } \\
\text { - Bottom-up } \\
\text { estimating } \\
\text { - PM software }\end{array}$ & $\begin{array}{l}\text { - Activity resource } \\
\text { requirements } \\
\text { - Resource } \\
\text { breakdown } \\
\text { structure (RBS) } \\
\text { - Project document } \\
\text { updates }\end{array}$ \\
\hline $\begin{array}{l}\text { Estimate } \\
\text { Activity } \\
\text { Durations }\end{array}$ & $\begin{array}{l}\text { - Schedule management } \\
\text { plan } \\
\text { - Activity list } \\
\text { - Activity attributes } \\
\text { - Activity resource } \\
\text { requirements } \\
\text { - Resource calendars } \\
\text { - Project scope statement } \\
\text { - Risk register } \\
\text { - RBS } \\
\text { - EEF } \\
\text { - OPA }\end{array}$ & $\begin{array}{l}\text { - Expert judgment } \\
\text { - Analogous } \\
\text { estimating } \\
\text { - Parametric } \\
\text { estimating } \\
\text { - Three-point } \\
\text { estimating } \\
\text { - Group decision } \\
\text { making } \\
\text { - Reserve analysis }\end{array}$ & $\begin{array}{l}\text { - Activity duration } \\
\text { estimates } \\
\text { - Project documents } \\
\text { updates }\end{array}$ \\
\hline $\begin{array}{l}\text { Develop } \\
\text { Schedule }\end{array}$ & $\begin{array}{l}\text { - Schedule management } \\
\text { plan } \\
\text { - Activity list } \\
\text { - Activity attributes } \\
\text { - Project schedule } \\
\text { network diagrams } \\
\text { - Activity resource } \\
\text { requirements } \\
\text { - Resource calendars } \\
\text { - Activity duration } \\
\text { estimates } \\
\text { - Project scope statement } \\
\text { - Risk register } \\
\text { - Project staff } \\
\text { assignments } \\
\text { - RBS } \\
\text { - EEF } \\
\text { - OPA }\end{array}$ & $\begin{array}{l}\text { - Schedule network } \\
\text { analysis } \\
\text { - Critical path } \\
\text { method } \\
\text { - Critical chain } \\
\text { method } \\
\text { - Resource } \\
\text { optimization } \\
\text { techniques } \\
\text { - Modeling } \\
\text { techniques } \\
\text { - Leads and lags } \\
\text { - Schedule } \\
\text { compression } \\
\text { - Scheduling tool }\end{array}$ & $\begin{array}{l}\text { - Schedule baseline } \\
\text { - Project schedule } \\
\text { - Schedule date } \\
\text { - Project calendars } \\
\text { - PM plan updates } \\
\text { - Project documents } \\
\text { updates }\end{array}$ \\
\hline $\begin{array}{l}\text { Control } \\
\text { Schedule }\end{array}$ & $\begin{array}{l}\text { - Project management } \\
\text { plan } \\
\text { - Project schedule } \\
\text { - Work performance data } \\
\text { - Project calendars } \\
\text { - Schedule data } \\
\text { - OPA }\end{array}$ & $\begin{array}{l}\text { - Performance } \\
\text { reviews } \\
\text { - PM software } \\
\text { - Resource } \\
\text { optimization } \\
\text { - Modeling } \\
\text { techniques } \\
\text { - Leads and lags } \\
\text { - Schedule } \\
\text { compression } \\
\text { - Scheduling tool }\end{array}$ & $\begin{array}{l}\text { - Work performance } \\
\text { information } \\
\text { - Schedule forecasts } \\
\text { - Change requests } \\
\text { - PM plan updates } \\
\text { - Project documents } \\
\text { updates } \\
\text { - OPA updates }\end{array}$ \\
\hline
\end{tabular}

Project life cycle consists of four phases [14, 15]: project initiation, project planning, project execution, and project closure. Figure 2 illustrates the project life cycle [16]. There is a feedback between each two phases. For example, through the planning phase, the SP manager may discover that the documented project background ignores some facts in the reality. Therefore, there is a feedback between initiating the project and planning the project to redefine the project background. Each phase includes a set of processes to achieve it, but it is out of this paper scope. The performance of project managers can be effectively measured for a specific SPM knowledge area because each area includes a set of processes and skills related to a specific SPM competency. The knowledge areas are a handy way to group together theory and practical techniques [13]. It can help in discovering the weaknesses in a specific area that can be led to more attention to this area. Therefore, this is the main focus of the novel measuring method proposed in the paper.

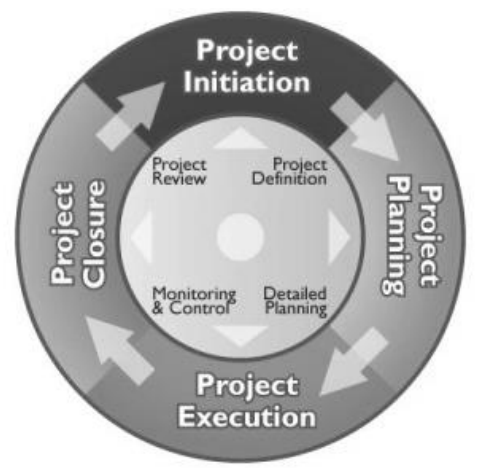

Fig. 2. Project life cycle [16]

\section{B. SPM Performace Metrics and Indicators}

Performance measurement is the ongoing monitoring and reporting of project accomplishments, particularly progress towards pre-established goals [17]. This process is used in project management and quality processes to determine and communicate status and accomplishments measured against specific objectives, schedules, and milestones. These measurements extend to include delivery of desired products and services to customers, whether external or internal. Performance measurement can be useful to improve future work estimates [18]. Performance measures may address: the type or level of project process conducted, the direct products and services delivered by a program, and/or the results of those products and services [17].

A metric is a quantitative measure of the degree to which a system, component, or process possesses a given attribute [19]. Metrics can be used for measuring the performance of SP manager. Performance metrics should be objective, timely, simple, accurate, useful, and cost-effective. Performance metrics can be divided into three basic categories [17]: measures of efforts, measures of accomplishments, and measures that relate efforts to accomplishments.

- Measures of efforts: Efforts are the amount of resources, in terms of money, people, etc., applied to a project. Examples: The amount of money spent and the number of person-hours burned on a project.

- Measures of accomplishments: Accomplishments are milestones achieved with the resources used. Examples 
include: number of modules coded and number of deliverables.

- Measures that relate efforts to accomplishments: These measures are associated with resources or cost relative to accomplishments achieved. Examples may include: amount of money expended for the portion of project completed versus the amount of money planned to be expended for this portion of work.

Mike Denley proposes a list of metrics related to project cost and schedule management [20] that shown in table III.

\section{TABLE III. Metrics of ProJect Cost AND SCHEdule MANAGEMENT} [20]

\begin{tabular}{|l|l|}
\hline $\begin{array}{l}\text { Knowledge } \\
\text { Area }\end{array}$ & Metric \\
\hline \multirow{4}{*}{$\begin{array}{l}\text { Project Cost } \\
\text { Management }\end{array}$} & $\begin{array}{l}\text { \% Deviation Planned Vs. Actual Margin } \\
\text { hours }\end{array}$ \\
\cline { 2 - 2 } & \% unplanned project hours completed /estimated Project \\
\cline { 2 - 3 } & Cost Deviation From Planned Budget \\
\cline { 2 - 2 } & Estimate to Complete (ETC) (cost) \\
\cline { 2 - 2 } & $\begin{array}{l}\text { Value at Completion (VAC) } \\
\text { Budget at Completion (BAC) }\end{array}$ \\
\hline \multirow{4}{*}{$\begin{array}{l}\text { Project } \\
\text { Schedule }\end{array}$} & \%anagement Number of Milestones Missed \\
\cline { 2 - 2 } & $\begin{array}{l}\text { Deviation From Project / Program Time } \\
\text { Schedule }\end{array}$ \\
\cline { 2 - 2 } & Planned Vs. Actual Project End Date \\
\cline { 2 - 2 } & Schedule Variance \\
\hline
\end{tabular}

Performance metrics can be useful in calculating performance indicators for SP manager. An indicator can be defined as a function of metrics. Figure 3 illustrates the relationships between SPM knowledge areas, metrics, measures, and indicators.

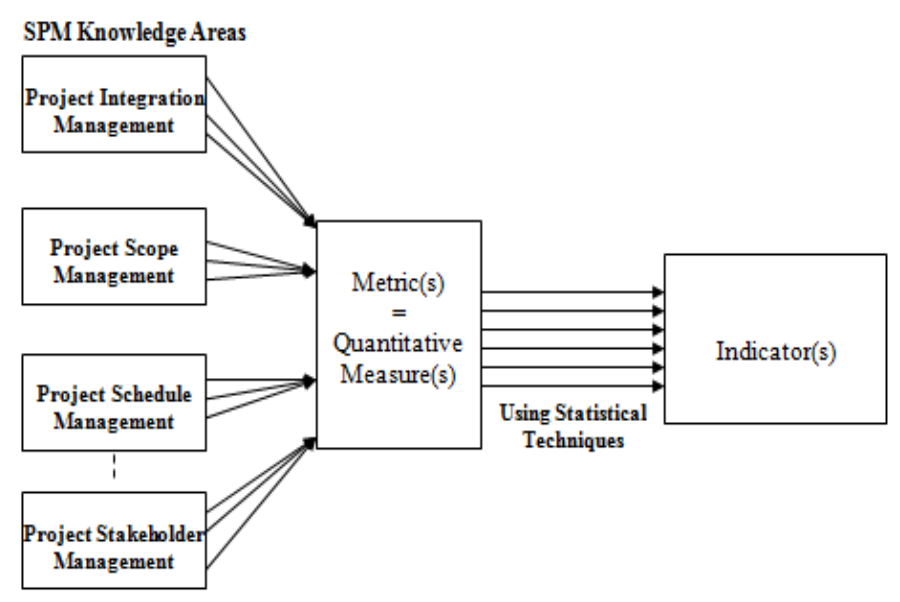

Fig. 3. SPM knowledge areas, metrics, measures, and indicators

Calculating metrics is a simple process because it depends on simple or known mathematical formulas such as percentage, ratio, present value, and time deviation (in hours, days, weeks, or months). On the other hand, calculating indicators from metrics is not an easy process because the indicator value may depend on a combination of metrics and each of them doesn't have the same level of importance and they may not have the same nature [17].

\section{Goal Question Metrics (GQM) Method}

Victor Basili and et al at Maryland University developed a goal oriented approach for measurement [21]. GQM method was developed for multi-purpose evaluation of software [22]. This method depends on three steps:

1) Set goals specific to needs in terms of purpose, perspective, and environment.

2) Refine the goals into quantifiable questions that are tractable.

3) Deduce the metrics and data to be collected (and the means for collecting them) to answer the questions.

In GQM method, each goal generates a set of quantifiable questions that attempt to define and quantify this goal. The question can only be answered relative to, and as completely as, the available metrics allow. In GQM, the same question can be used to define multiple goals. Also, metrics can be used to answer more than one question. Figure 4 illustrates the hierarchy of goals, questions, and metrics of GQM method [23]. In this paper, the researcher provides a new adapted version of GQM method to measure the performance of SP managers.

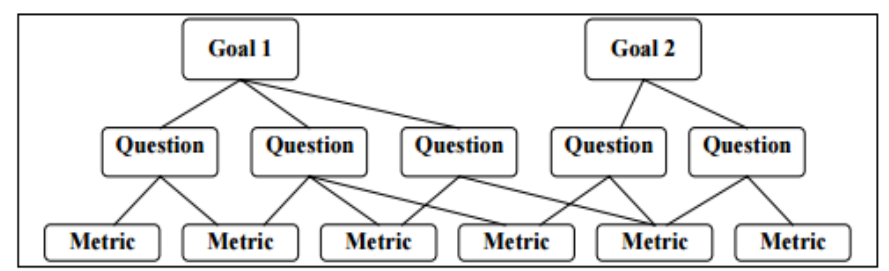

Fig. 4. GQM method [23]

\section{RELATED WORK}

There are many studies conducted to describe the performance of SP managers and provide some guidance on the factors affecting their success. Some other studies provide simple and little ideas about performance measurement. In the following, some examples of these studies are presented:

- Andrew Stellman and Jennifer Greene [2] provide a practical guide for managing a software project effectively. They present the common pitfalls that plague all software projects and rookie mistakes that are made repeatedly. They present the tools, techniques, best practices, and practical advices that can be used on software projects for building better software. They cover many performance issues, but they don't cover performance metrics issues.

- Basharat et al. [24] describes different factors that cause the success or failure of projects. Their results present general guidance for project managers to make sure that their projects be successful. This study shows the importance of project management tools and techniques in the industry. It also shows how project management is important for a successful and quality software product.

- J. Procaccino and J. Verner [25] examine the mindset of software development project managers with regard to how they define a successful project in order to arrive at 
a richer perspective of success. They investigated components of the developed system in order to place traditional measures of success in context with other organizational and managerial measures that have been suggested in the literature. They conclude that involvement of users and stakeholders during project development is an important success factor.

- Mirza and et al. [26] discuss that scope should be properly defined and controlled and what can be the major factors behind mismanagement of scope and how it can be overcome. It is concluded that a better appreciation of the distinction between project and product scope can bring a higher possibility of project success within the planned cost and schedule.

- J. Verner and W. Evanco [27] surveyed 42 software projects in Australia in order to understand what project management practices are used in these projects. The relationship between practices and software project outcomes enables the authors to investigate why some projects succeed and others fail. They found that nearly $20 \%$ of projects had no lifecycle methodology and $10 \%$ of the respondents did not understand what was meant by a software development lifecycle methodology. Many recognized software practices are not being applied consistently in the projects investigated. Fifty percent of projects began with unclear requirements. Risk assessment is not normally a part of the development process and the organizations are not learning from their mistakes as post mortem reviews are much more likely to be held for successful projects than they are for failed projects.

- Paul Pocatilu [28] stated that in order to have successful projects, lessons learned have to be used, historical data to be collected and metrics and indicators have to be computed and used to compare them with past projects and avoid failure to happen. He presents some metrics that can be used for IT project management. He concluded that the quality of calculating metrics depends on the quality of data used in the model.

- Kanhaiya Jethani [29] discusses the benefits of choosing appropriate metrics and analysis method based on observations in several organizations. It also discusses the pitfalls of choosing wrong metrics. Organizations can define useful metrics for the software development process by using the GQM method, which ensures that the metrics are aligned with the goals of the organization. Examples of metrics for software development process and some of the pitfalls of inappropriate metrics definition based on observations in various organizations have been provided for guidance. Simple metrics analysis methods for various metrics have also been provided for reference.

- Julio Menezes and et al. [30] present the application of a systematic mapping study that aims to raise related work to the usage of metrics and indicators for risk assessment in multiple projects' environments. They conclude that the study of risk measurement in software development environments should be seen more carefully, taking into account the aspects of software processes, especially with the increasing of agile methods, which requires a more sophisticated development culture, impacting directly on software processes.

- Terence L. Woodings and Gary A. Bundell [31] define a taxonomy of software metrics which is derived from the needs of users, developers, and management. The properties of the classifications are discussed. A number of approaches (e.g. the Software Factory, CMM, Bootstrap, SPICE, GQM, Balanced Scorecard), have been advocated for the systematic design and introduction of software metrics for the purposes of process improvement and capability assessment in an organization. Rules are then derived which generate a new set of metrics from an existing class. The rules complement standard approaches by focusing attention on user driven aspects of an organization's measurement program. They do this by directly linking product characteristics with organizational improvements. The method also has promise as an approach for validating process models and metrics. Examples of the theoretical and pragmatic use of the taxonomy are provided. The paper concludes with a discussion of useful applications.

- Maarit Tihinen [32] discusses challenges in current measurement practices have been summarized and described in detail from a GSD viewpoint. Further, requirements for dynamic measurements derived from GSD-related challenges in current measurement practices have been introduced. This thesis defines dynamic measurements as actions where metrics are defined or updated based on the needs of each project and demands of each project's collaboration setting. The actual metrics data are collected and analyzed continuously from various tools and databases, even from stakeholders' databases, and results of measurements are analyzed with visualized indicators that are easy to read. This thesis introduced a technical implementation that was utilized as a proof of concept for the measurement-based management of GSD projects.

- Ž. Antolić [33] presents an overview of possible Key Performance Indicators (KPI) that can be used for software process efficiency evaluation. The overview is based on currently used KPIs in software development projects on Cello Packet Platform (CPP) platform. The most important KPIs are analyzed, and their usage in the process efficiency evaluation is discussed. The outcome of the measurement is used to initiate further process adjustments and improvements.

\section{GOAL QUESTION METRIC INDICATOR (GQMI) METHOD}

The researcher proposes an adapted version of GQM method which is illustrated in figure 5. The adapted version of GQM method exceeds one step rather than the original one. The additional step is calculating the performance indicator for 
each SPM knowledge area, therefore the adapted version of GQM will be entitled Goal Question Metric Indicator (GQMI) Method. However, the four steps of GQMI are:

1) Define goals for each SPM knowledge area.

2) Refine the goals into quantifiable questions that must be answered for each goal.

3) Deduce performance metrics that can be used to answer the questions. Then, calculate the value of performance metrics.

4) Calculate performance indicators that can be calculated for each SPM knowledge area.

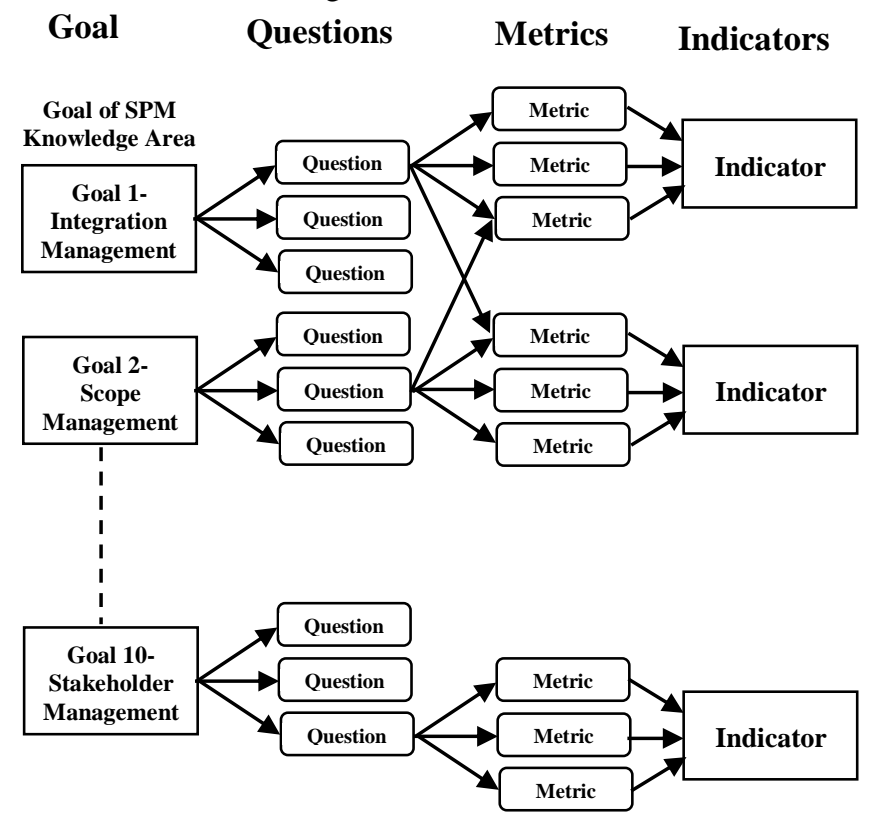

Fig. 5. GQMI Method

\section{A. Define Goals for each SPM Knowledge Area}

Each SPM knowledge area has a goal that represents the conceptual level of GQM method. A goal is defined for an object, for a variety of reasons, with respect to various models of quality, from various points of view, relative to a particular environment [23]. In this paper, the performance of SP managers is the main focus; therefore a goal is expressed as the performance of the project manager in a specific SPM knowledge area. For example, the goal related to the knowledge area "project integration management" is "improving the performance of the project manager in project integration management". Similarly, the goals of the rest nine SPM knowledge areas can be defined.

\section{B. Refine the Goals into Quantifiable Questions}

A set of questions is used to characterize the way the assessment/achievement of a specific goal is going to be performed [23]. The questions that are typically used for characterizing the performance of the SP manager are collected from various references and then purified and classified into groups, where each group relates to a specific SPM knowledge area. The result is a list of questions that represents each knowledge area and can be used for deducing performance metrics that will be explained in the next sub-section. The following is an example of questions related to project schedule/time management:

- Q1: How is the schedule management plan developed?

- Q2: How are the activities defined?

- Q3: How are the activities sequenced?

- Q4: How is the activity resources estimated?

- Q5: How is the activity durations estimated?

- Q6: How is the schedule developed?

- Q7: How is the schedule controlled?

\section{Deduce Performance Metrics}

There are many performance metrics of SPM that can be used for answering the questions of each SPM knowledge area. These metrics can be used for evaluating the performance of SP manager. But, not all metrics have the same degree of importance or efficiency in measuring the performance, therefore each metric must have a weight to express its importance. The typical method of weighting is assigning the weights 1,2 , or 3 for each metric. A weight 3 is used to show the performance metric of the most importance. A weight 1 is used to show the performance metric of the lowest importance. A weight 2 is used to show the performance metric of the average importance. The researcher tries to prepare an enhanced list of performance metrics and their weights.

For the purpose of this paper, an initial list of performance metrics is prepared from published SPM literatures and opinions of experts. Then, the initial list of metrics is subjected to validation process to produce the enhanced list of performance metrics. The researcher validates the performance metrics using a questionnaire that is prepared and delivered to 60 experts and specialists in SPM. The questionnaire includes the nine SPM knowledge areas as goals, each goal decomposes into a set of questions that is used to characterize the way of achieving it, and each question can be answered through a set of metrics. The respondents were originally classified into three equal groups:

- The first group includes 20 SP managers in different domains.

- The second group includes 20 professionals who work as team members in SPs.

- The third group includes 20 academic staff members who are interested in SPs. 
The actual number of respondents who completed the questionnaire was 48 . The respondents were required to select the effective metrics from the available list in the questionnaire. In addition, they were required to determine the weight of each metric. After collecting the responses, the researcher filtered the questions and metrics to reach an enhanced list of metrics. The definition of each metric should include the mathematical or statistical techniques for calculating this metric. The enhanced list will include the most effective questions and metrics that may make it more practical and efficient. Table IV presents the enhanced list of questions and performance metrics for schedule/time project management as an example of SPM knowledge areas. The majority of metrics in table IV have the importance degree 3; that is because the researcher attempts to extract the most effective metrics. In addition, the metric "M5" in question "Q1" is same as the metric "M4" in question "Q7". Similarly, the metric "M3" in question "Q2" and the metric "M3" in question "Q7". The complete definition of the performance metrics should also include:

- The mathematical or statistical techniques for calculating each metric.

- The planning and/or actual data required for calculating each metric.

- The required implementation range for each performance metric. The required implementation range is the acceptable range of the performance metric.

At the end of this step, a complete definition of performance metrics is reached in the form of an enhanced list. Then, the performance metrics can be calculated either for one or more SPM knowledge areas.

\section{Calculate Performance Indicators}

The enhanced list of performance metrics resulted from the previous sub-section is used for calculating performance indicators for SP manager in each SPM knowledge area. This process can help in improving capability level, productivity, and performance. Calculating indicators from metrics is not an easy process because the indicator value may depend on a combination of metrics and each of them doesn't have the same level of importance and they may not have the same nature [17]. The source of complexity is due to the different nature of the data types of the performance metrics. They may include ROI, PV, percentage, ratio, number of days, or/and numeric amounts.

Therefore, it is important to use a method to unify these values to be entered into indicators calculation process. Therefore, the researcher uses a rating scale for measuring the implementation of the performance metrics. The proposed scale is based on that each performance metric value is compared with the required implementation range, and typically the following rules are applied:

- If the metric value is in the required range, the implementation value will be "Accepted" or equal the numeric value "2".
TABLE IV. THE ENHANCED LIST OF QUESTIONS AND PERFormanCE METRICS FOR SCHEDULE/TIME MANAGEMENT

\begin{tabular}{|c|c|c|}
\hline Questions & Metrics & $\mathbf{W}$ \\
\hline \multirow{5}{*}{$\begin{array}{l}\text { Q1: How is } \\
\text { the schedule } \\
\text { management } \\
\text { plan } \\
\text { developed? }\end{array}$} & $\begin{array}{l}\text { M1. Percentage of schedule management procedures included in } \\
\text { the plan vs the standard or predefined procedures. }\end{array}$ & 3 \\
\hline & $\begin{array}{l}\text { M2. Percentage of actual inputs included in the process vs } \\
\text { planned inputs. }\end{array}$ & 3 \\
\hline & $\begin{array}{l}\text { M3. Percentage of techniques and tool used vs possible or } \\
\text { effective techniques and tool for this activity. }\end{array}$ & 2 \\
\hline & $\begin{array}{l}\text { M4. Percentage of the attributes of schedule management plan } \\
\text { implemented vs required. }\end{array}$ & 3 \\
\hline & $\begin{array}{l}\text { M5. Ratio of number of modifications applied to schedule } \\
\text { management plan vs required. }\end{array}$ & 3 \\
\hline \multirow{8}{*}{$\begin{array}{l}\text { Q2: How are } \\
\text { the activities } \\
\text { defined? }\end{array}$} & $\begin{array}{l}\text { M1. Percentage of actual inputs included in the process vs } \\
\text { planned inputs. }\end{array}$ & 3 \\
\hline & $\begin{array}{l}\text { M2. Percentage of techniques and tool used vs possible or } \\
\text { effective techniques and tool for this activity. }\end{array}$ & 3 \\
\hline & $\begin{array}{l}\text { M3. Percentage of schedule management procedures applied vs } \\
\text { planned. }\end{array}$ & 3 \\
\hline & $\begin{array}{l}\text { M4. Percentage of activities included in the activity list resulted } \\
\text { from this process vs all defined. }\end{array}$ & 3 \\
\hline & $\begin{array}{l}\text { M5. Percentage of activities that have completed attributes vs all } \\
\text { activities in the activity list. }\end{array}$ & 3 \\
\hline & $\begin{array}{l}\text { M6. Percentage of external milestones included in the external } \\
\text { milestone list vs identified in the contract. }\end{array}$ & 3 \\
\hline & $\begin{array}{l}\text { M7. Percentage of internal milestones included in the internal } \\
\text { milestone list vs identified by the custom. }\end{array}$ & 2 \\
\hline & $\begin{array}{l}\text { M8. Ratio of internal milestones to external milestones included } \\
\text { in the milestone list. }\end{array}$ & 1 \\
\hline \multirow{4}{*}{$\begin{array}{l}\text { Q3: How are } \\
\text { the activities } \\
\text { sequenced? }\end{array}$} & $\begin{array}{l}\text { M1. Percentage of actual inputs included in the process vs } \\
\text { planned inputs. }\end{array}$ & 3 \\
\hline & $\begin{array}{l}\text { M2. Percentage of techniques and tool used vs possible or } \\
\text { effective techniques and tool for this activity. }\end{array}$ & 3 \\
\hline & $\begin{array}{l}\text { M3. Percentage of activities that were subjected to dependency } \\
\text { analysis vs all activities in the activity list. }\end{array}$ & 3 \\
\hline & $\begin{array}{l}\text { M4. Percentage of project activities sequenced in project } \\
\text { schedule network diagrams vs all activities in the activity } \\
\text { list. }\end{array}$ & 3 \\
\hline \multirow{4}{*}{$\begin{array}{l}\text { Q4: How is the } \\
\text { activity } \\
\text { resources } \\
\text { estimated? }\end{array}$} & $\begin{array}{l}\text { M1. Percentage of actual inputs included in the process vs } \\
\text { planned inputs. }\end{array}$ & 3 \\
\hline & $\begin{array}{l}\text { M2. Percentage of techniques and tool used vs possible or } \\
\text { effective techniques and tool for this activity. }\end{array}$ & 3 \\
\hline & M3. Percentage of alternatives were analyzed vs all alternatives. & 3 \\
\hline & $\begin{array}{l}\text { M4. Percentage of activities that were subjected to resources } \\
\text { estimation vs all activities in the activity list. }\end{array}$ & 3 \\
\hline \multirow{4}{*}{$\begin{array}{l}\text { Q5: How is the } \\
\text { activity } \\
\text { durations } \\
\text { estimated? }\end{array}$} & $\begin{array}{l}\text { M1. Percentage of actual inputs included in the process vs } \\
\text { planned inputs. }\end{array}$ & 3 \\
\hline & $\begin{array}{l}\text { M2. Percentage of techniques and tool used vs possible or } \\
\text { effective techniques and tool for this activity. }\end{array}$ & 3 \\
\hline & $\begin{array}{l}\text { M3. Percentage of activities that were subjected to duration } \\
\text { estimation vs all activities in the activity list. }\end{array}$ & 3 \\
\hline & $\begin{array}{l}\text { M4. Percentage of estimates that were subjected to reviews vs } \\
\text { all estimates. }\end{array}$ & 2 \\
\hline \multirow{4}{*}{$\begin{array}{l}\text { Q6: How is the } \\
\text { schedule } \\
\text { developed? }\end{array}$} & $\begin{array}{l}\text { M1. Percentage of actual inputs included in the process vs } \\
\text { planned inputs. }\end{array}$ & 3 \\
\hline & $\begin{array}{l}\text { M2. Percentage of techniques and tool used vs possible or } \\
\text { effective techniques and tool for this activity. }\end{array}$ & 3 \\
\hline & $\begin{array}{l}\text { M3. Percentage of activities used in developing schedule vs all } \\
\text { activities in the activity list. }\end{array}$ & 3 \\
\hline & $\begin{array}{l}\text { M4. Percentage of schedule reviews that were performed before } \\
\text { finalizing the schedule vs identified by the custom. }\end{array}$ & 2 \\
\hline \multirow{9}{*}{$\begin{array}{l}\text { Q7: How is the } \\
\text { schedule } \\
\text { controlled? }\end{array}$} & $\begin{array}{l}\text { M1. Percentage of actual inputs included in the process vs } \\
\text { planned inputs. }\end{array}$ & 3 \\
\hline & $\begin{array}{l}\text { M2. Percentage of techniques and tool used vs possible or } \\
\text { effective techniques and tool for this activity. }\end{array}$ & 3 \\
\hline & $\begin{array}{l}\text { M3. Percentage of schedule management procedures applied vs } \\
\text { planned. }\end{array}$ & 3 \\
\hline & $\begin{array}{l}\text { M4. Ratio of number of modifications applied to schedule } \\
\text { management plan vs required. }\end{array}$ & 3 \\
\hline & $\begin{array}{l}\text { M5. Percentage of tasks completed vs. planned at a point of } \\
\text { time. }\end{array}$ & 3 \\
\hline & M6. Percentage of external milestones met vs. planned. & 3 \\
\hline & M7. Percentage of internal milestones met vs. planned. & 2 \\
\hline & M8. Percentage of project deliverables achieved vs. planned. & 3 \\
\hline & M9. Slippage time of the project schedule (in days). & 3 \\
\hline
\end{tabular}


- If the metric value is greater than the required range, the implementation value will be "Highly Accepted" or equal the numeric value " 3 ". Some metrics can't exceed the required range; therefore this rule isn't applied in this case.

- If the metric value is less than the required range, the implementation value will be "Not Accepted" or equal the numeric value " 1 ".

The previous rules can't be applied to some metrics such as the metrics "M9" in question "Q7". If the slippage time is greater than the required range, the implementation value will be "Not Accepted" or equal the numeric value " 1 ". If the slippage time is less than the required range, the implementation value will be "Highly Accepted" or equal the numeric value " 3 ". In addition, some performance metrics may be Not Applicable (NA) in some cases [34]. During computing the performance indicators, the not applicable quality metrics will be eliminated.

For achieving the purpose of the proposed model, the performance metrics are organized in a table as in table $\mathrm{V}$. The performance indicator can be calculated using the weighted mean method. The weighted mean method is appropriate because it takes the weights into account during calculations [34]. The basic formula of the weighted mean is [35]:

\section{Weighted Mean $=\left(\sum\right.$ Xi.Wi $) / \sum W i$}

Where:

$\mathrm{Xi}$ is the implementation value of the performance metric $\mathrm{i}$

Xi may take the value 1,2 , or 3 according to the rating the lowest importance, average importance, or the most importance respectively.

$\mathrm{Wi}$ is the metric weight of each performance metric $\mathrm{i}$. It may take the value 1,2 , or 3 .

Based on to the rating scale that is used, the performance indicator value will range from 1 to 3 . According to the proposed measuring method and the data listed in table $\mathrm{V}$, the performance indicator for schedule/time can be calculated using the weighted mean equation for each question or for all the knowledge area.

Performance indicator for "Q 1 " $=(3 \times 2+3 \times 3+2 \times 2+3 \times 1$ $+3 \times 1) /(2+3+2+1+1)=2.78$ out of $3=92.67 \%$

Similarly, the performance indicator for "project schedule/time management" can be calculated $=1.8$ out of $3=$ $60 \%$

After calculating the value of the performance indicator for a specific SPM knowledge area, this value must be compared with the acceptable value of performance indicator. Then, the result of comparison should be analyzed to discover the weakness and strength points of SPM performance. The analysis may return to the performance indicators of questions to reveal which of them contribute in increasing or decreasing the value of the performance indicator. Based on the analysis of results, top management may take supportive or corrective actions. The acceptable value of the performance indicator is used for judging the calculated value. If the acceptable value of performance indicator is 2.4 out of 3 . Therefore, performance indicator of "project schedule/time management" isn't acceptable and the value of the performance indicator for each question should be analyzed because each one represents a process required for achieving the knowledge area.

TABle V. The ACtual VAlues of PERformance Metrics For SCHEDULE/TIME MANAGEMENT

\begin{tabular}{|c|c|c|c|c|c|c|}
\hline Question & Metric & $\begin{array}{l}\text { Metric } \\
\text { Weight } \\
\text { Wi }\end{array}$ & $\begin{array}{l}\text { Required } \\
\text { Range }\end{array}$ & $\begin{array}{l}\text { Actual Value } \\
\text { of the } \\
\text { Metrics }\end{array}$ & NA & $\begin{array}{l}\text { Implementation } \\
\text { Value } \\
\mathbf{X i}\end{array}$ \\
\hline \multirow{5}{*}{ Q1 } & M1 & 3 & $80-90 \%$ & $90 \%$ & & 2 \\
\hline & M2 & 3 & $80-90 \%$ & $95 \%$ & & 3 \\
\hline & M3 & 2 & $70-80 \%$ & $75 \%$ & & 2 \\
\hline & M4 & 3 & $85-95 \%$ & $60 \%$ & & 1 \\
\hline & M5 & 3 & $1: 1$ & $4: 6$ i.e. $<1: 1$ & & 1 \\
\hline \multirow{8}{*}{ Q2 } & M1 & 3 & $80-90 \%$ & $80 \%$ & & 2 \\
\hline & M2 & 3 & $70-80 \%$ & $80 \%$ & & 2 \\
\hline & M3 & 3 & $85-95 \%$ & $80 \%$ & & 1 \\
\hline & M4 & 3 & $90-95 \%$ & $100 \%$ & & 3 \\
\hline & M5 & 3 & $90-95 \%$ & $100 \%$ & & 3 \\
\hline & M6 & 3 & $100 \%$ & $80 \%$ & & 1 \\
\hline & M7 & 2 & $85-95 \%$ & $95 \%$ & & 2 \\
\hline & M8 & 1 & $1: 1$ & $1: 1$ & & 2 \\
\hline \multirow{4}{*}{ Q3 } & M1 & 3 & $80-90 \%$ & $80 \%$ & & 2 \\
\hline & M2 & 3 & $70-80 \%$ & $80 \%$ & & 2 \\
\hline & M3 & 3 & $100 \%$ & $100 \%$ & & 2 \\
\hline & M4 & 3 & $100 \%$ & $100 \%$ & & 2 \\
\hline \multirow{4}{*}{ Q4 } & M1 & 3 & $80-90 \%$ & $95 \%$ & & 3 \\
\hline & M2 & 3 & $70-80 \%$ & $70 \%$ & & 2 \\
\hline & M3 & 3 & $80-90 \%$ & & $\checkmark$ & \\
\hline & M4 & 3 & $80-90 \%$ & $80 \%$ & & 2 \\
\hline \multirow{4}{*}{ Q5 } & M1 & 3 & $80-90 \%$ & $80 \%$ & & 2 \\
\hline & M2 & 3 & $70-80 \%$ & $80 \%$ & & 2 \\
\hline & M3 & 3 & $80-90 \%$ & $80 \%$ & & 2 \\
\hline & M4 & 2 & $80-90 \%$ & $70 \%$ & & 1 \\
\hline \multirow{4}{*}{ Q6 } & M1 & 3 & $80-90 \%$ & $90 \%$ & & 2 \\
\hline & M2 & 3 & $70-80 \%$ & $60 \%$ & & 1 \\
\hline & M3 & 3 & $100 \%$ & $100 \%$ & & 2 \\
\hline & M4 & 2 & $85-95 \%$ & $70 \%$ & & 1 \\
\hline \multirow{9}{*}{ Q7 } & M1 & 3 & $80-90 \%$ & $80 \%$ & & 2 \\
\hline & M2 & 3 & $70-80 \%$ & $80 \%$ & & 2 \\
\hline & M3 & 3 & $85-95 \%$ & 80 & & 1 \\
\hline & M4 & 3 & $1: 1$ & $4: 6$ i.e. $<1: 1$ & & 1 \\
\hline & M5 & 3 & $85-95 \%$ & $70 \%$ & & 1 \\
\hline & M6 & 3 & $80-90 \%$ & $80 \%$ & & 2 \\
\hline & M7 & 2 & $80-90 \%$ & $70 \%$ & & 1 \\
\hline & M8 & 3 & $85-95 \%$ & $95 \%$ & & 2 \\
\hline & M9 * & 3 & 14 days & 25 days & & 1 \\
\hline
\end{tabular}

\section{APPLYING GQMI METHOD ON REAL SOFTWARE PROJECTS}

To achieve the purpose of this paper, GQMI has been applied on 3 real SPs to evaluate the performance of SP managers.

- The first project aimed to develop a software application for inventory control in an agriculture company.

- The second project aimed to develop a software application for managing training department in a pharmaceutical company. 
- The third project aimed to develop a software application for managing procurement department in a beverage company.

The performance metrics were calculated for schedule/time management. Table VI illustrates the actual data of the three projects.

TABLE VI. The ApPlication of GQMI on Three Software Projects

\begin{tabular}{|c|c|c|c|c|c|}
\hline \multirow{2}{*}{ Question } & \multirow{2}{*}{ Metric } & \multirow{2}{*}{\begin{tabular}{|l} 
Metric \\
Weight \\
Wi
\end{tabular}} & \multicolumn{3}{|c|}{ Implementation Value Xi } \\
\hline & & & Project (1) & Project (2) & Project (3) \\
\hline \multirow{5}{*}{ Q1 } & M1 & 3 & 2 & 3 & 2 \\
\hline & M2 & 3 & 3 & 3 & 2 \\
\hline & M3 & 2 & 2 & 3 & 2 \\
\hline & M4 & 3 & 1 & 3 & 2 \\
\hline & M5 & 3 & 1 & 1 & 2 \\
\hline \multirow{8}{*}{ Q2 } & M1 & 3 & 2 & 2 & 1 \\
\hline & M2 & 3 & 2 & 3 & 2 \\
\hline & M3 & 3 & 1 & 3 & 1 \\
\hline & M4 & 3 & 3 & 2 & 2 \\
\hline & M5 & 3 & 3 & 2 & 3 \\
\hline & M6 & 3 & 1 & 2 & 2 \\
\hline & M7 & 2 & 2 & 3 & 3 \\
\hline & M8 & 1 & 1 & 2 & 1 \\
\hline \multirow{4}{*}{ Q3 } & M1 & 3 & 2 & 2 & 2 \\
\hline & M2 & 3 & 2 & 2 & 2 \\
\hline & M3 & 3 & 2 & 2 & 1 \\
\hline & M4 & 3 & 2 & 2 & 2 \\
\hline \multirow{4}{*}{ Q4 } & M1 & 3 & 3 & 2 & 1 \\
\hline & M2 & 3 & 2 & 2 & 2 \\
\hline & M3 & 3 & 1 & 2 & 3 \\
\hline & M4 & 3 & 2 & 3 & 3 \\
\hline \multirow{4}{*}{ Q5 } & M1 & 3 & 2 & 2 & 1 \\
\hline & M2 & 3 & 2 & 3 & 2 \\
\hline & M3 & 3 & 2 & 2 & 1 \\
\hline & M4 & 2 & 1 & 2 & 2 \\
\hline \multirow{4}{*}{ Q6 } & M5 & 3 & 2 & 3 & 2 \\
\hline & M6 & 3 & 1 & 3 & 3 \\
\hline & M7 & 3 & 2 & 2 & 2 \\
\hline & M8 & 2 & 1 & 2 & 3 \\
\hline \multirow{9}{*}{ Q7 } & M1 & 3 & 2 & 3 & 3 \\
\hline & M2 & 3 & 2 & 3 & 1 \\
\hline & M3 & 3 & 1 & 3 & 2 \\
\hline & M4 & 3 & 2 & 2 & 2 \\
\hline & M5 & 3 & 1 & 3 & 3 \\
\hline & M6 & 3 & 2 & 3 & 2 \\
\hline & M7 & 2 & 1 & 2 & 3 \\
\hline & M8 & 3 & 2 & 3 & 2 \\
\hline & M9 & 3 & 1 & 2 & 1 \\
\hline \multicolumn{2}{|l|}{$\sum$} & $\sum \mathrm{Wi}_{107}$ & $\sum$ Xi.Wi=192 & $\sum \mathrm{Xi} . \mathrm{Wi}=260$ & $\sum$ Xi.Wi=213 \\
\hline \multicolumn{3}{|c|}{$\begin{array}{l}\text { The Indicator Value }= \\
\text { Weighted Mean }=\left(\sum \mathrm{Xi} . \mathrm{Wi}\right) / \sum \mathrm{Wi}\end{array}$} & 1.79 & 2.43 & 1.99 \\
\hline
\end{tabular}

According to table VI, the performance of the project manager for schedule/time management of project (2) is the best because he has more experience and applies some agile practices. The performance of the project manager for schedule/time management of project (1) is the worst because he hasn't the sufficient experience and there are problems in the project team. Figure 6 illustrates the comparison between the performances of the three project managers for schedule/time management of the three projects. Figure 7 illustrates the value of the performance indicator for each question related to project (1).

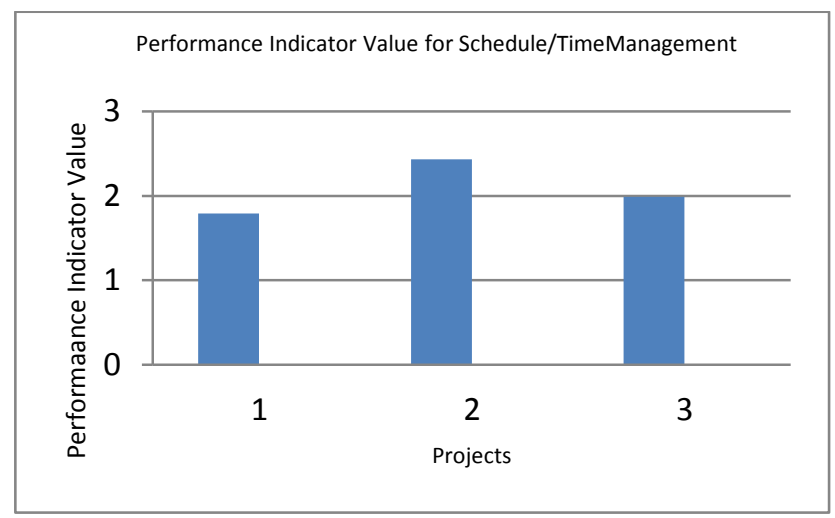

Fig. 6. The comparison between the performances of the three project managers

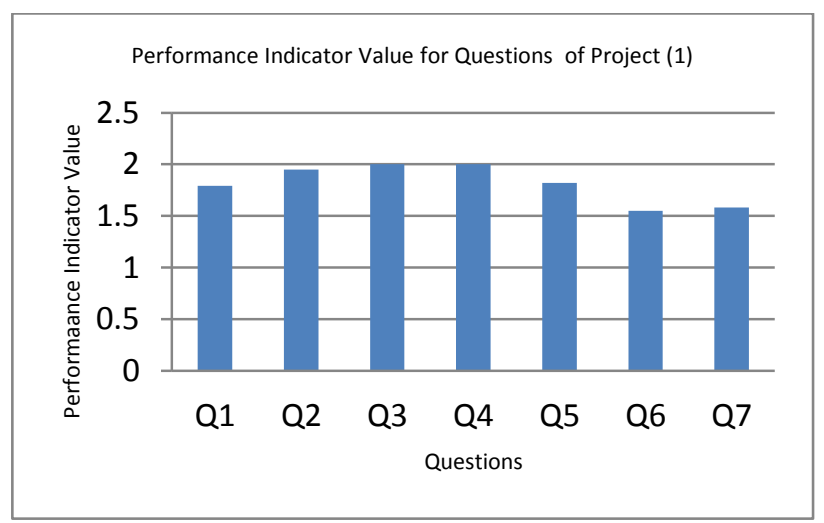

Fig. 7. The value of the performance indicator for each question related to project (1)

\section{CONCLUSION}

The performance of project managers can be effectively measured for a specific SPM knowledge area because each area includes a set of processes and skills related to a specific SPM competency. This paper aimed to measure the performance of SP managers through a novel method that is based on GQM method, an enhanced list of performance metrics for SPM knowledge areas, and a combination of simple mathematical and statistical techniques to calculate performance indicators for SP managers. The novel method depends on defining goals for each SPM knowledge area, refining the goals into quantifiable questions that must be answered for each goal, deducing performance metrics that can be used to answer the questions, and calculating performance indicators for each SPM knowledge area. In addition, the performance indicator can be calculated for each question that represents a process related to the knowledge area. The researcher focused on schedule/time management as an example of knowledge areas to explain the novel measuring method. In addition, he applied the novel method on three real SPs. Finally, the researcher concludes that measuring the performance of SP managers can provide an attention to pitfalls in their performance and may be helpful in controlling and improving the performance. 


\section{FUTURE WORK}

There are many issues related to the performance of SP mangers can be tackled in the future:

- Expanding the work to build an automated software tool for evaluating the performance indicators of SPM knowledge areas.

- Adapting GQMI method to be used for agile SPs.

- Adapting GQMI method to be used in cloud computing applications.

- Measuring the performance of the project managers of e-government projects.

\section{REFERENCES}

[1] Information Systems Audit and Control Foundation (ISACF),"Project Management: Skill and Knowledge Requirements in an Information Technology Environment", 2002.

[2] Andrew Stellman and Jennifer Greene, "Applied Software Project Management”, O'Reilly Media, ISBN 978-0-596-00948-9, 2005.

[3] Jeffrey A. Hoffer, Joey F. George,and Joseph S. Valacich, "Modern System Analysis and Design", Addison Wesley Longman, Inc, 1999.

[4] https://www.tutorialspoint.com/software_engineering/software_project_ management.htm Last visit: 4/10/2016

[5] Jeffrey L. Whitten, Lonnie D. Bentley and Kevin C.Dittman, "System Analysis and Design Methods", Fifth edition, Mc Graw Hill Companies, Inc, 2001.

[6] Nagy Ramadan Darwish and Nancy M. Rizk, "Multi-Dimensional Success Factors of Agile Software Development Projects", International Journal of Computer Applications (IJCA), Vol. 118 No. 15, Page: 23-30, Foundation of Computer Science, New York, USA, May 2015.

[7] CHAOS manifesto 2013, Standish Group International.

[8] Project Management Institute (PMI), "A Guide to the Project Management Body of Knowledge - PMBOK Guide", 5th edition, 2013.

[9] Project Management Institute (PMI) and IEEE Computer Society, "Software Extension to the PMBOK Guide (5th Edition)", 2013.

[10] Mary Sumner, "Risk Factors in Enterprise Wide Information Management Systems Projects", ACM press, New York, NY, USA, Proceedings of the 2000 ACM SIGCPR Conference on Computer Personnel Research, 180-187.

[11] Hallows, Jolyon E., CMC, "Information Systems Project Management: How to Deliver Function and Value in Information Technology Projects", AMACOM, a division of American Management Association, 1998.

[12] Mary Sumner, "Critical Success Factors in Enterprise Wide Information Management Systems Projects", ACM press, New York, NY, USA, Proceedings of the 1999 ACM SIGCPR Conference on Computer Personnel Research, 297-303, 1999.

[13] https://www.project-management-prepcast.com/pmbok-knowledgeareas-and-pmi-process-groups last visit: 22/10/2016.

[14] Daniele Di Filippo,Russell D. Archibald,and Ivano Di Filippo,"SixPhase Comprehensive Project Life Cycle Model", Vol. I, Issue V, December 2012.

[15] Jason Westland,'Project management guidebook", Method123, 2003.
[16] http://www.method123.com/project-lifecycle.php last visit: 4/10/2016.

[17] Department of Energy (DOE), "Basic Performance Measures for Information Technology Projects", 2002, http://energy.gov/sites/prod/files/cioprod/documents/PerMeasTech-V3011502.pdf Last visit: 29/9/2016.

[18] Karl E. Wiegers, "A Software Metrics Primer", Process Impact, 1999, http://www.processimpact.com/articles/metrics_primer.html

[19] IEEE Standard 610,"Glossary of Software Engineering", 1990.

[20] Mike Denley, "Metric-Driven Project Management Driving Success by Design", Siemens PLM Software, http://www.elysiuminc.com/gpdis/2015/Siemens-

Denley_DrivingtoSuccessbyDesign_PDST_Open.pdf Last visit: 4/10/2016.

[21] Fenton, Norman, Robin Whitty and Yoshinori lizuka, "Software Quality Assurance and Measurement", International Thomson Computer Press, 1995.

[22] Zdena Dobešová1 and Dagmar Kusendová2, "Goal-Question-Metric method for evaluation of cartographic functionality in GIS software", proceedings GIS Ostrava, 2009, www.geoinformatics.upol.cz/app/visegrad/images/GISOstrava.pdf

[23] Victor R. Basili, Gianluigi Caldiera, and H. Dieter Rombach, "THE GOAL QUESTION METRIC APPROACH", 1994.

[24] Basharat Jehan, Kamran Ghani, and Muhammad Shafi, "Assessment of Project Management Practices in Pakistan Software Industry", IEEE SCONEST 2014, At Hyderabad Pakistan, 2014.

[25] J. Procaccino and J. Verner, "Software project managers and project success: An exploratory study", Journal of Systems and Software, Vol. 79, No. 11, pp. 1541-1551, 2006.

[26] Muhammad Nabeel Mirza, Zohreh Pourzolfaghar, and Mojde Shahnazari, "Significance of Scope in Project Success", Procedia Technology, Volume 9, Pages 722-729, 2013.

[27] J. Verner and N. Cerpa, "Australian Software Development: What Software Project Management Practices Lead to Success?", Proceedings of the 2005 Australian Software Engineering Conference (ASWEC'05), IEEE, 2005.

[28] Paul Pocatilu, "IT Project Management Metrics", Revista Informatica, 4 (44), 2007.

[29] Kanhaiya Jethani, "Software Metrics for Effective Project Management", International Journal of System Assurance Engineering and Management, pages 335-340, Vol. 4 No. 4, December 2013.

[30] Júlio Menezes Jr., Cristine Gusmão, and Hermano Moura, "Indicators and Metrics for Risk Assessment in Software Projects: A Mapping Study", Laboratório de Banco de Dados, Universidade Federal de Minas Gerais, 2012.

[31] Terence L. Woodings and Gary A. Bundell, "A framework for software project metrics", Proceedings of the 12th European Conference on Software Control and Metrics, 2001.

[32] Maarit Tihinen, "Measurement-based management of global software development projects", Ph.D. Thesis, VTT SCIENCE 70, University of Oulu, Finland, October 2014.

[33] Ž. Antolić, "An Example of Using Key Performance Indicators for Software Development Process Efficiency Evaluation", Internal Ericsson Documentation, Croatia, January 2008.

[34] William E Perry, "Quality Assurance for Information Systems: Methods, Tools, and Techniques", QED technical publishing Group, 1991.

[35] Abdul Quader Miah, "Applied Statistics for Social and Management Sciences", Springer 2016. 